\title{
Everyday Lawmaking in International Human Rights Law: Insights from the Inclusion of Domestic Violence in the Prohibition of Torture
}

\author{
Natalie R. Davidson
}

\begin{abstract}
How is international human rights law (IHRL) made "everyday" outside of treaty negotiations? Leading socio-legal accounts emphasize transnational civil society activism as a driver of norm change but insufficiently consider power dynamics and the legal-institutional environment. This article sheds light on these dimensions of IHRL by reconstructing how domestic violence came to be included in the prohibition of torture in five international and regional human rights institutions. Through process tracing based on interviews and a vast amount of documentation, the study reveals everyday lawmaking in IHRL as a complex, incremental process in which a wide range of actors negotiate legal outcomes. The political implications of this process are ambiguous as it enables participation while creating hidden sites of power. In addition to challenging existing models of international norm change, this study offers an in-depth empirical exploration of a key development in the international prohibition of torture and demonstrates the benefits of process tracing as a socio-legal methodology.
\end{abstract}

\section{INTRODUCTION}

How is international human rights law (IHRL) made? Who writes IHRL, and who shapes the evolution of its norms? These questions are important for understanding this area of law and evaluating its legitimacy as well as for assessing whether activists should continue to view it as an arena within which to promote social change, especially at a time when IHRL is under attack from both conservative and progressive corners. Accused for a few decades of being a form of Western, liberal imperialism (Brown 2004), IHRL has been more recently denounced as an undemocratic rule by experts (Koskenniemi 2018).

Natalie R. Davidson is a Lecturer at the Buchmann Faculty of Law, Tel Aviv University, Ramat Aviv, Israel. Email: davidson@tauex.tau.ac.il

I thank Adi Dubson, Nour Gandour, Mila Kirpichnikov, and Noam Morris for excellent research assistance, and Nofar Kadosh, Gilad Mor, and Stacy Belden for editing. Many thanks to Daphna Hacker, Janet Halley, Eliav Lieblich, Tamar Megiddo, the participants in the Tel Aviv University International Law Workshop, and the anonymous reviewers for very helpful comments and to Dan Brinks, Tomer Broude, and Hila Shamir for encouraging me to pursue this project. Research for this article was supported by the Israel Science Foundation, Grant no. 1938/19, and approved by Tel Aviv University's ethics committee. 
The foundational instruments in IHRL are the Universal Declaration of Human Rights and numerous international and regional treaties. ${ }^{1}$ State officials and civil society actors from the global North and South played key roles in drafting these documents (Glendon 2002; Normand and Zaidi 2008; Lerner 2015). Yet these instruments form only a small part of the story. International lawyers now recognize the centrality of courts and other bodies in what I call "everyday lawmaking" in IHRL: lawmaking outside of treaty drafting in the routine processes of interpretation such as adjudication and periodic reviews of state reports. How does this everyday lawmaking unfold? Who has influence over the outcomes, and what is the nature of the interaction among the participants? How do institutional features of IHRL enable and constrain these interactions and normative change?

The leading accounts of international norm change in the area of human rights can be roughly split along a politics/law divide. Constructivist international relations scholars emphasize the efforts of "norm entrepreneurs" in deliberately promoting norms they deem appropriate (Finnemore and Sikkink 1998). Under this account, IHRL is an arena that can be shaped by social movements if they strategize and struggle sufficiently. Yet, as noted by Ezgi Yildiz (2020), constructivists have not given much attention to how norms evolve once they are legalized. Moreover, constructivists view law too narrowly as a set of tools, ignoring the ways in which the legal-institutional environment in which activists pursue change may shape the lawmaking process, the power relations among participants, and the normative outcome itself.

Unsurprisingly, legal scholars are more attuned to the legal-institutional specificities of IHRL. Notably, Gráinne de Búrca (2017) suggests viewing the work of the United Nations (UN) treaty bodies (established to interpret and monitor implementation of international human rights treaties) as a form of experimentalist governance. In experimentalism, norms are initially set to be vague. Actors at the periphery then contribute to the revision and specification of those norms through recurring periodic inputs to the center. This account portrays lawmaking in IHRL as a more complex, participatory, and incremental process than suggested by constructivists. However, the model does not pay attention to power relations and struggles over interpretations and, therefore, cannot explain why some legal interpretations win over others.

This article sheds light on some of the socio-legal dynamics in everyday lawmaking in IHRL at the international level, paying attention both to the legal-institutional context and to the power relations among participants. It argues that norm change in IHRL does not occur through a linear process of activism but, rather, through numerous incremental steps by a wide range of actors-victims, grassroots and elite civil society actors, state officials, legal experts, and international bureaucrats. These actors leverage legal features of IHRL - in particular, the ubiquity of non-binding ("soft") law and the fragmentation of the field into multiple regimes and bodies. The political implications of this complex process are ambiguous. On the one hand, the process is participatory: it creates openings for subordinate actors to contribute to lawmaking and spreads control of norm change among a wide range of actors negotiating legal outcomes. On the other hand, unequal power relations among civil society actors persist, and actors in hidden

1. Universal Declaration of Human Rights, GA Res. 217A (III), UNGAOR, 3rd Sess., Supp no. 13, UN Doc A/810 (1948). 
sites of power exert influence. Moreover, while these legal-institutional specificities of IHRL enable much normative creativity, they also constrain radicalism because they heighten path dependence.

The argument is developed through a reconstruction of how domestic violence came to be included in the category of torture and its companion "cruel, inhuman or degrading treatment" (CIDT) in IHRL. This particular norm change is a fruitful case through which to explore everyday lawmaking in IHRL since it is expected to conform to existing models and can therefore challenge some of their propositions and highlight their blind spots. The prohibitions of torture and CIDT are core norms in IHRL. The principal international documents and institutional practices addressing these prohibitions have traditionally reflected the view that they relate to the exercise of public power. The 1984 UN Convention against Torture, of which this definition is the "benchmark" (Rodley 2002, 474), requires the involvement of an official and the presence of some purpose typically linked to the state, such as obtaining a confession. ${ }^{2}$ Article 16 of the convention also prohibits "cruel, inhuman or degrading treatment or punishment which do not amount to torture ... when such acts are committed by or at the instigation of or with the consent or acquiescence of a public official or other person acting in an official capacity." Similarly linking torture to the way public power is exercised, theoreticians explain its prohibition as "emblematic of our determination to break the connection between law and brutality" (Waldron 2005, 1739).

In Velásquez-Rodriguez, a case concerning disappearance by paramilitary forces in Honduras, the Inter-American Court of Human Rights (IACtHR) held in 1988 that a state could be held responsible for a human rights violation committed by a private person because of the state's lack of due diligence in preventing the violation or responding to it. ${ }^{3}$ Yet the IACtHR and other bodies who subsequently adopted similar interpretations remained within the area of public power: their expansions of state obligations were primarily applied to informal delegations of power from the state to paramilitary groups, and they were developed at least partly to overcome evidentiary difficulties proving state action (Rodley 2002, 486).

Invoking Velásquez-Rodriguez, feminist lawyers in the early 1990s argued that domestic violence is a form of torture. Through engagements with international law since the 1980s, they had already succeeded in placing domestic violence in the newly framed category of "violence against women," a category that was appealing due to its ability to bridge cultural and geographic differences (Keck and Sikkink 1998, 170-71). In the 1990s, a number of international declarations and treaties set out states' obligations to prevent and punish acts of violence against women, even when perpetrated by private persons. Yet bringing private violence into the purview of IHRL generally was not deemed sufficient for those lawyers steeped in what Janet Halley (2019, 35-39) terms "power feminism," a structuralist approach focusing on male domination and female subordination. The prohibition of torture, the heart of IHRL, became a target for "feminization" (Edwards 2006). Catharine MacKinnon (1993) juxtaposed descriptions of official torture and the suffering of women in private settings to critique IHRL's

2. Convention against Torture and Other Cruel, Inhuman or Degrading Treatment or Punishment, December 10, 1984, 1465 UNTS 85 (Convention against Torture).

3. IACtHR, Velásquez-Rodriguez v. Honduras, Merits, Judgment (Ser. C) No. 4 (July 29, 1988). 
focus on state action and its neglect of violence suffered primarily by women. In a highly influential article published in 1994, Rhonda Copelon (1994, 196-295), cofounder and then director of the International Women's Human Rights Clinic at the City University of New York's Law School (CUNY Clinic), argued that the inclusion of domestic violence in the prohibition of torture was needed to provide an enforceable legal tool to impose state responsibility and to de-trivialize the violence suffered by women in their homes. The peremptory character of the prohibition of torture, and the state obligations it gives rise to (such as exercising universal jurisdiction) made the inclusion of domestic violence in the prohibition particularly significant (Davis 2017, 351-52).

These objectives have been met to a large extent. Between the late 1990s and mid2010s, the principal institutions that produced the definition of torture in IHRLnamely, the Committee against Torture (CAT), the Human Rights Committee (HRC), the European Court of Human Rights (ECtHR), the Inter-American Commission of Human Rights (IACHR), and the IACtHR began to hold states responsible for violating the prohibition of CIDT and torture when failing, under certain conditions, to prevent or address domestic violence. Specifically, the CAT has explicitly linked domestic violence to torture; the IACtHR has categorized it as CIDT, while the other institutions do not clearly distinguish between the two when discussing domestic violence. Feminists lament the failure of all institutions to clearly classify domestic violence as torture. Nevertheless, the extent of the norm change is remarkable, expanding the purview of torture/CIDT, which is traditionally concerned with state violence, to the most private forms of violence (Davidson 2019).

Feminist scholars have mapped these legal developments, attributing them to feminist legal activism (Edwards 2006, 2010; Davis 2017). In its emphasis on ideationally motivated activists, the feminist account is largely compatible with the constructivist approach, presenting IHRL as a site that can be mobilized successfully through concerted strategizing. But how exactly did this interpretation of the norm prohibiting torture/CIDT win the day in the institutions of IHRL? Was this change the outcome of a struggle or was it smoothly accepted? Who were the feminists' allies and what were their motivations? How did legal and institutional characteristics of each institution, and of the system as a whole, enable, constrain, and shape this normative change?

To answer these questions, this study engages in process tracing of how domestic violence came to be framed as torture or CIDT at the international level in the CAT, the HRC, the IACtHR, the IACHR, and the ECtHR, based on interviews and on a vast amount of documentation. ${ }^{4}$ The findings reveal everyday lawmaking in IHRL as a complex process carrying both emancipatory and hegemonic implications. They demonstrate the importance for norm change of three practices within IHRL: the hardening of soft (non-binding) law, the consolidation of interpretations across a fragmented field, and grafting - namely, the incremental growth of state obligations building on the achievements of previous activists. While these practices, and, more generally, the

4. The study included neither the Committee on the Elimination of Discrimination against Women (CEDAW) (which does not monitor the prohibition of torture/cruel, inhuman, or degrading treatment [CIDT]) nor the African Court and Commission on Human and Peoples' Rights (which have not issued rulings addressing domestic violence as a violation of torture/CIDT). 
law and procedure of IHRL, have enabled creativity and participation, they have also constrained the radicalism of norm development because they have heightened path dependence, reproduced inequalities, and concealed the power wielded by key actors.

The first part of this article situates this study in the scholarship about norm change in IHRL. The second part discusses the study's methodology. The third part recounts how domestic violence came to be included in the prohibition of torture/CIDT in each institution. The fourth part offers a systemic analysis of the findings across institutions, and the conclusion discusses the study's implications.

\section{NORM CHANGE IN IHRL}

Formally, international law develops principally through evolutions in treaties and custom, sources traditionally understood to depend on the consent or behavior of states. Court decisions and the publications of experts are only relevant insofar as they help interpret these primary sources. However, even among international lawyers lacking a socio-legal bent, the myth that courts do not themselves write international law has been debunked in the face of the proliferation of international dispute settlement institutions and expert bodies (Cohen 2012, 275-76).

Such judicialization is especially apparent in IHRL. Any lawyer attempting to understand IHRL norms will study regional human rights court and commission rulings as well as the publications of the nine committees established to monitor UN human rights treaties, which are staffed by experts who, though elected by states, do not act in a representative capacity (referred to as "committees" or "treaty bodies" and their members as "experts" or "members"). ${ }^{5}$ These committees produce three types of publication indicative of their legal interpretations: (1) decisions on individual communications alleging a state's violation of the relevant treaty for states authorizing communications; (2) concluding observations on a state's compliance with its treaty obligations, issued at the end of the treaty body's periodic review of the state; and (3) general comments, setting out the treaty body's interpretation of a certain aspect of the treaty, often as a consolidation of its jurisprudence and concluding observations. The legal authority of concluding observations and general comments is certainly contested. In concluding observations, committees express concern and offer recommendations, in the spirit of "constructive dialogue" with states. While general comments are formulated explicitly as legal interpretations, their authority is debated. Some states point to the fact that they are not mentioned in the treaties setting the committees' mandate (Keller and Grover 2012, 118), and domestic courts and even the ECtHR have held that they lack binding authority. ${ }^{6}$ Nevertheless, they are a source of at least persuasive authority that cannot be ignored.

5. These are the Committee on the Elimination of Racial Discrimination, the Committee on Economic, Social and Cultural Rights, the Human Rights Committee (HRC), the CEDAW, the Committee against Torture (CAT), the Committee on the Rights of the Child (CRC), the Committee on Migrant Workers, the Committee on the Rights of Persons with Disabilities, and the Committee on Enforced Disappearances.

6. Kazemi Estate v. Islamic Republic of Iran, 2014 SCC 62, 146-47; ECtHR, Jones and Others v. United Kingdom, Application nos. 34356/06, 40528/06 (January 14, 2014), 208. 
It is equally clear to many commentators that civil society activists such as human rights non-governmental organizations (NGOs) play a crucial part in developing IHRL, whether by representing claimants, submitting third party briefs before regional human rights courts, submitting "shadow reports" and other information to treaty bodies reviewing states' periodic reports, and participating in treaty bodies' consultations toward the drafting of general comments. Rich accounts of international conferencing and treaty making in IHRL as well as in the related area of international criminal law emphasize the lawmaking role of civil society actors, and feminist groups, in particular, alongside state actors (Engle 2005; Merry 2006, 36-71; Halley 2008; Naftali 2010).

The view that a largely progressive elite of judges, experts, and legal activists shapes IHRL is also reflected in the main theory of norm change in the field. The norm life cycle model draws on case studies of advocacy campaigns for norm change-in particular, for the recognition of women's rights. Its authors operate within an agentist constructivist approach-that is, they envision international norms as socially constructed and focus on how agents strategize to shape these norms (Finnemore and Sikkink 2001, 400-3). The model posits that a stage of norm emergence, during which individuals deliberately construct and promote a norm they deem appropriate, is sometimes followed by a stage of norm institutionalization, wherein a critical mass of followers accepts and in turn promotes the norm. The process is completed with a stage of norm internalization, in which actors and institutions take the norm for granted (Finnemore and Sikkink 1998, 895-905). In the first stage, ideationally motivated "norm entrepreneurs" try to gather critical support by persuasion and framing. If successful, the norm becomes broadly accepted by states or international organizations, leading to a "norm cascade" through accelerated imitation. The authors of the model consider norms resonating with human dignity, such as bodily integrity and equality, to be particularly persuasive as they are common to many cultures. Though these scholars borrow concepts such as norm entrepreneur from legal scholarship, the model is not specifically legal. However, they explain that, since 1948, institutionalization typically takes place in international law, and they and other scholars have used this model to explain the emergence of new legal human rights norms (Naftali 2010).

For many lawyers, the trajectory of IHRL is one of linear progress (Alston 2013, 2063) and increased protection (Lagoutte, Gammeltoft-Hansen, and Cerone 2016, 7). Critical scholars challenge this view by exposing the historical and cultural contingencies of IHRL (Chimni 2004). The constructivist approach underlying the norm life cycle model, like the critical perspective, envisions human rights norms as socially constructed. However, constructivists focus on the social practices underlying norm change, drawing special attention to social movement activism. For constructivists, IHRL is less a lackey of states in the North than it is the product of civil society, including from the South. Constructivists have devoted a lot of attention to one type of norm entrepreneur: networks of non-state actors, including NGOs, called "transnational advocacy networks." These networks comprise "those relevant actors working internationally on an issue, who are bound together by shared values, a common discourse, and dense exchanges of information and services," allowing "nontraditional international actors to mobilize information strategically to help create new issues and categories to persuade, pressure, and gain leverage over much more powerful organizations and governments" (Keck and Sikkink 1998, 2). Shifting attention from idealistic individuals to the 
networks themselves, constructivist scholarship now emphasizes the role played by "gatekeepers" (Bob 2011) or "network hubs" (Carpenter 2011) such as leading Western NGOs in certifying new rights and rights expansions as worthy of activism, identifying the internal and external politics of these leading NGOs — and not just ideational motivations - as factors explaining why some issues get selected for advocacy over others.

Recent constructivist scholarship on human rights activism has taken a more institutionalist turn. Beyond networks, it now pays attention to activists' "political opportunity structure," defined as "the broader institutional and international environment in which NGOs are embedded" (Joachim 2007, 7). This structure includes rules of procedure that give access to international bodies and existing normative frameworks-legal and moral precedents — on which activists can build. Indeed, among the techniques used by activist networks, scholars have highlighted "grafting," "the combination of active, manipulative persuasion and the contingency of genealogical heritage in norm germination" (Price 1998, 616). To illustrate, Richard Price (1998) argues that activists succeeded in delegitimizing land mines by drawing on the existing moral opprobrium against other indiscriminate weapons, such as chemical weapons.

The rich constructivist literature exploring issue emergence focuses on choices made within the NGO world. Struggles over interpretations of rights within the legal arena are largely relegated to a matter of successful or unsuccessful persuasion of states by activists. While the state is clearly an actor in the elaboration of IHRL, it appears in the constructivist account either as an obstacle or an ally in a program defined by civil society-hence, Price's $(1998,639)$ statement that transnational civil society "teaches" the state how to behave. But, in the highly institutionalized world of IHRL, might norm change involve not only persuading states but also negotiating with them and finding overlapping interests with state actors and legal staff?

Moreover, legal scholarship suggests that, despite increased attention to the institutional environment, the constructivist account views law too narrowly as a procedural opportunity for access and a repository of precedents. ${ }^{7}$ Scholars have pointed to the role played by soft law in enabling actors to fill in legal gaps and introduce new concepts and enabling others (typically, corporations) to resist the codification of new norms (Shelton 2003, 1; Lagoutte, Gammeltoft-Hansen, and Cerone 2016). Similarly, the experimentalist account of IHRL emphasizes the importance of the abstract formulation of rights in treaties, and the lack of tools of enforcement (de Búrca 2017). In experimentalist governance, actors at the periphery contribute to the revision and specification of initially vague norms through periodic inputs to the center. In IHRL, the abstractness and lack of enforceability of the legal formulations enable actors in each state to develop their particular local interpretation of rights, which they in turn communicate to the treaty bodies through state reports and NGO shadow reports. This model aligns with accounts of the recursivity of processes of transnational lawmaking (Halliday and Carruthers 2007; Halliday and Block-Lieb 2017).

The understanding of a complex process of lawmaking among a multiplicity of actors questions the constructivist account of a well-coordinated struggle for norm

7. Constructivist scholarship on norm effectiveness, however, exhibits sensitivity to the question of whether norms are legally binding (Finnemore 1999; see also Simmons 2009, 7). 
change. Yet the experimentalist account also approaches norm change too narrowly. It does not explore power relations and struggles over interpretations, even though studies of lawmaking in other areas of international law show that the structure of the lawmaking process affects interactions among participants and their relative power (Halliday and Block-Lieb 2017, 10). Moreover, focused on the local-global dynamic of lawmaking, the experimentalist model considers each treaty body in isolation and therefore misses the systemic dynamics across IHRL. In particular, it ignores the much-discussed practice of cross-referencing among international bodies, a central manifestation of transnational judicial dialogue (Slaughter 2003; Voeten 2010). This practice has been explained, among other things, as an attempt by courts to buttress the legitimacy of their interpretations (Seibert-Fohr 2015) and as dependent on judicial ideology (Voeten 2010). These explanations suggest that processes of norm change in IHRL combine legal and political techniques that connect the various institutions in the field.

This article explores lawmaking in IHRL by bringing together and building upon the insights of constructivist and legal scholarship, paying close attention to both the legal-institutional environment and power relations. With respect to legal features, the study considers not only abstractness and lack of enforceability but also relations among international institutions in a fragmented field, rules of procedure, as well as argumentative and bureaucratic practices. With respect to power dynamics, it explores not only strategic activism and struggles among NGOs but also relations between NGOs and other actors and the power of institutional actors such as junior bureaucrats. As such, this study echoes what Paul Ingram and Karen Clay $(2000,526)$ call "choice-withinconstraints" neo-institutionalism, examining how individuals pursue their goals within institutional constraints, including rules and cultural norms.

\section{METHODOLOGY}

The categorization of domestic violence as torture/CIDT offers a fruitful site in which to pursue such an endeavor as it is a "critical case" with respect to the norm life cycle. A critical case is one with strategic importance in relation to the theory since it is "likely to either clearly confirm or irrefutably falsify propositions and hypotheses" (Flyvbjerg 2006, 231). The present case was led by feminist advocates consciously striving to change the law and is therefore expected to conform to the norm life cycle model. The case's exploration can accordingly challenge some of the model's propositions. In addition, because it concerns a central norm of IHRL, this case has enabled the exploration of norm change across institutions with varying characteristics, including those claimed to be experimentalist. It also facilitates tracing transnational dynamics across the various institutions in the field and highlights blind spots in the experimentalist account.

The author, assisted by four research assistants, engaged in minute process tracing (George and Bennett 2005, 6). This methodology was employed to understand how domestic violence was categorized as torture/CIDT: which actors were involved, how they interacted, what was the nature of the process, and what were the institutional constraints and opportunities. The researchers traced when and how domestic violence began to be framed as torture in the five major institutions that produce the definition of 
torture in IHRL: the CAT, the HRC, the IACtHR, the IACHR, and the ECtHR. The research team, headed by the author, collected and searched all documents constitutive of the norm before these institutions: general comments, concluding observations, and decisions on individual communications issued by the CAT and the HRC, as well as all the jurisprudence of the IACtHR, the IACHR, and the ECtHR, for mentions of domestic violence and related forms of mistreatment by private actors in connection with the prohibition of torture or CIDT. For the publications of the HRC and the CAT, as well as the rulings of the ECtHR, the search included all documents since the establishment of those institutions and ceased once the categorization of domestic violence as torture/ CIDT had become recurrent (2002 for the HRC, 2004 for the CAT, and 2013 for the ECtHR). The search with respect to the IACtHR and IACHR, which produce less case law, included all publications to date. The researchers treated as a legal data point each such mention of domestic violence.

For each data point, the researchers then traced who raised the issue before the institution and how. For instance, a NGO could have raised the issue of domestic violence by filing a shadow report before the CAT, or an expert on the CAT could have raised the issue at a meeting with the state delegation. Such process tracing was conducted through an analysis of several hundred documents reflecting the procedures that preceded the production of a legal data point: state reports to treaty bodies, shadow reports by NGOs, correspondence between treaty bodies, states and other actors (including lists of issues issued by treaty bodies to states), summary records of treaty body meetings (where the discussions at the meetings are recorded in summary form, indicating who said what), audio and video recordings of regional court hearings, concluding observations, communications, general comments, case law, and party and third-party submissions. These documents are accessible on the websites of the regional institutions and of the Office of the High Commissioner for Human Rights, except for $\mathrm{NGO}$ shadow reports before treaty bodies, which are only available from the mid-2000s, and party and third-party submissions before regional courts, which can be found online with respect to most, but not all, relevant cases.

Having identified the legal data points and traced the actors and proceedings that produced them, the author analyzed the relevant actors' motivations as well as the institutional and political constraints and opportunities of those actors and of the deciding bodies. This second, more interpretative stage of analysis drew on the documents used in process tracing as well as ten in-depth, semi-structured, open-ended interviews with lawyers, NGO representatives, and institution officials, which were selected among the actors identified during process tracing as having been involved in, or present during, the production of legal data points. The interviews, most of which were conducted over Zoom, covered the interviewees' careers, the circumstances and extent of interaction with the relevant institutions, the subjects' objectives in the interaction, the coalitions and partnerships created, as well as the challenges experienced. Some central participants in the process had passed away or were not willing to be interviewed; for them, as for the interviewees, the author relied on articles and published speeches.

The interviews, articles, and speeches served two main purposes. First, they provided factual information, which served to fill gaps in the process tracing and triangulate findings from other data. Second, the author sought to elicit the actors' experiences and motivations through the information that the subjects transmitted expressly as well as 
through discourse analysis that paid attention to the topics foregrounded and backgrounded by the actor; his or her reaction to the questions; and vocabulary and references. This analysis clarified the actor's ideological perspective (whether the subject used a radical feminist discourse, for instance) and the issues that were important to them. Most interviewees produced lengthy narratives in which they expressed a range of emotions as their stories progressed. For this reason, the author was able to rely on these interviews as sources about the interviewees' motivations and constraints, even though the interviewees' perspectives today may reasonably be expected to differ from what they were at the time. Nevertheless, the interviews, like other sources, were analyzed with consideration for their limitations and the context in which they were produced. For instance, some interviewees assigned themselves a central role in the case they were describing. Where it appeared from the interview or from other sources that there had been a conflict over the control of the case, the author approached the interviewee's statements more as claims than as fact, unless corroborated by other sources. The interview transcripts as well as summaries and analyses of the other documents were coded for facts and recurring discursive themes using qualitative research software Nvivo.

\section{HOW DOMESTIC VIOLENCE BECAME TORTURE IN IHRL}

This part recounts how domestic violence came to be included in the prohibition of torture/CIDT. Because each institution developed its particular definition of torture/ CIDT, and the inclusion of domestic violence in this definition was the outcome of a distinct history before each of the institutions, this part describes each institution separately (the IACtHR and IACHR are treated jointly as the inter-American system), though connections among the institutions are pointed out. The fourth part will provide a systemic analysis of the findings.

\section{The CAT, 1998-2007}

The CAT was established in 1987 to monitor the Convention against Torture. ${ }^{8}$ This treaty, ratified by 169 states, focuses exclusively on torture/CIDT and is one of the rare treaties to contain a definition of torture. At the time of drafting, state parties clearly envisioned the convention relating to state violence only (Burgers and Danelius 1988, 119-20). Torture is defined as "any act by which severe pain or suffering, whether physical or mental, is intentionally inflicted on a person for such purposes as obtaining from him or a third person information or a confession, punishing him for an act he or a third person has committed or is suspected of having committed, or intimidating or coercing him or a third person, or for any reason based on discrimination of any kind, when such pain or suffering is inflicted by or at the instigation of or with the consent or acquiescence of a public official or other person acting in an official capacity." In her influential 1994 article, Rhonda Copelon (1994) argued that each of these

8. Convention against Torture.

9. Convention against Torture, Art. 1. 
elements of torture is found in domestic violence. In particular, the purpose requirement was met since violence against women, according to General Recommendation no. 19 published by the Committee on the Elimination of Discrimination against Women (CEDAW) in 1992, is a form of discrimination (CEDAW 1992). With respect to state involvement, she insisted that "the premise for treating gender-based domestic violence as a violation of human rights is that government-conferred impunity encourages this form of violence" (351).

These arguments would be echoed a decade later in discussions at the CAT about the inclusion of domestic violence in the committee's mandate. This inclusion occurred in two stages: between 1998 and 2004, domestic violence appeared as an issue for discussion in the concluding observations, and, between 2005 and 2007, the interpretation of domestic violence was solidified as falling within the CAT's mandate under certain conditions, according to General Comment no. 2, which provides that states bear responsibility where officials have knowledge or reasonable ground to believe violence is being committed by private actors, including domestic violence. ${ }^{10}$ Both stages are largely the work of Felice Gaer, the second woman to serve as an expert on the CAT from 2000 to 2014.

For a decade before being appointed to the CAT, Gaer, a US citizen, was involved on behalf of NGOs and as an appointee of the United States in rights advocacy at the UN. She was one of the initiators of CEDAW's General Recommendation no. 19 establishing that discrimination against women includes gender-based violence. When she joined the CAT, she was aware that the committee had been criticized for lacking a gender perspective. A 1998 report by the UN secretary general had noted that the committee's concluding observations never made reference to the situation of women (UN Secretary General 1998, para. 50). Gaer had originally planned to "follow the pattern of American senators" whereby a newcomer demonstrates that she is a respectful member of the body before attempting to make sweeping changes. But, as she recounted, that approach "lasted all of two mornings." Faced with the insistence by the chairman of the CAT that the topic was not within the committee's mandate, Gaer insisted on asking questions about gender-based violence, consciously "establishing a record ... in the review of countries." 11

To this end, she recalls obtaining factual information about the situation in each country from NGOs present at the UN in order to ask well-informed questions to state representatives. In addition, despite initial open confrontations with the chairman, Gaer decided to proceed gradually, first establishing that sexual violence in prisons was part of the CAT's mandate-a point that was difficult for states and experts to object to-before moving on to sexual and other violence in the home. Gaer found support in one of the other experts in the CAT, Andreas Mavrommatis, a former judge from Cyprus (all of the other experts were men in the first years of her mandate). In fact, according to the records, in most of the meetings with state representatives at which domestic violence was discussed until 2002, it was Mavrommatis who asked the questions, while Gaer asked about violence against women detainees. Gaer credits

10. General Comment no. 2: Convention against Torture and Other Cruel, Inhuman or Degrading Treatment or Punishment, Doc. CAT/C/GC/2 (2008).

11. Personal communication with Felice Gaer, interview via Whatsapp, April 9, 2020. 
Mavrommatis's experience at the HRC, where gender issues had been mainstreamed, for sensitizing him to the issue. She also surmises that domestic violence gave Mavrommatis an additional issue to discuss with states. She explained that, because the committee must afford equal treatment to all countries, it cannot be seen to hold shorter meetings with some. As a result, she sometimes noticed that "the most obscure issues would fill the time." Alternatively, in her recollection, experts occasionally tried to "throw softballs" to state representatives. ${ }^{12}$ At a time when many states were enacting domestic violence legislation, asking a question about that subject might have fulfilled such a goal.

Indeed, in the early years, some states even discussed domestic violence of their own initiative during their periodic review before the CAT. In 1997, Argentina's periodic report pointed to its ratification of the Inter-American Convention on the Prevention, Punishment and Eradication of Violence against Women (Belém do Pará Convention), a convention that emphasizes violence in the private sphere, as evidence of positive developments in the country with respect to the eradication of torture (CAT 1997, para. 11). ${ }^{13}$ Similarly, in 1999, at the first meeting of the Venezuelan delegation with the CAT (1999, para. 7), a state representative drew the committee's attention to the fact that Venezuela had enacted domestic violence legislation. As noted above, NGO shadow reports submitted in those years are not accessible, and it is possible that NGOs also raised this issue in addition to the state. However, this seems unlikely as the concluding observations issued by the CAT in each case retain the states' positive framing of the issue as demonstrating the state's progress. ${ }^{14}$ It is plausible that, by presenting recent enactments of legislation and accession to treaties addressing domestic violence as evidence of their progress in combating torture, these states attempted to deflect attention away from failures to comply with the prohibition of torture/CIDT in the traditional contexts of criminal justice or repression by the state.

In addition, some feminist state officials occasionally "encouraged," in Gaer's words, discussions of violence against women, probably in the hope of subsequently invoking the CAT's condemnation domestically. This is not to imply that states generally welcomed the inclusion of domestic violence in the CAT's mandate. Gaer recalls state resistance, expressed through comments such as "that question belongs in CEDAW." Moreover, she and another expert later appointed to the CAT recall resistance from male experts on the CAT until the mid-2000s. ${ }^{15}$

How, then, did domestic violence come to routinely appear in the CAT's concluding observations by 2004? In addition to Gaer's and Mavrommatis's regular questioning of state delegations, the committee's Secretariat, composed of lawyers employed by the $\mathrm{UN}$, began to include domestic violence among the list of issues that it sent to states in preparation for the their upcoming periodic reviews, starting in 2003. The Secretariat

12. Personal communication with Gaer, April 9, 2020.

13. Inter-American Convention on the Prevention, Punishment and Eradication of Violence against Women, June 9, 1994, OAS Treaty Series no. 68 (Belém do Pará Convention).

14. The shadow report submitted by Amnesty International with respect to Argentina does not mention domestic violence. Amnesty International, https://www.amnesty.org/download/Documents/156000/ amr130081997en.pdf.

15. Personal communication with Gaer, April 9, 2020; Personal communication with former CAT member, interview via Zoom, April 29, 2020. 
also occasionally assisted committee members in drafting concluding observations and, when doing so, echoed the discussions of domestic violence at the committee's sessions with states. ${ }^{16}$ Around the same time, consolidated working methods were adopted by the UN treaty bodies, including a format for each issue discussed of one paragraph of concerns followed by one paragraph of recommendations. The standardization of the concluding observations' format meant that the issue of domestic violence began to appear more regularly and took on a more legal shape-not simply an area of concern but one in which the committee issued recommendations, giving more precise meaning to state obligations.

A few years later, when arguing for the explicit inclusion in General Comment no. 2 of domestic violence, Gaer would insist that the general comment was simply consolidating years of committee practice in concluding observations (CAT 2008b, para. 6). ${ }^{17}$ Appointed as the committee's rapporteur on gender in 2000 , she consulted with leading specialists on gender-based violence and surveyed the work of the HRC, CEDAW, and other international bodies for inspiration about a concrete plan of action. One of the specialists she consulted was Copelon, who urged Gaer to draft a general comment on gender for the committee's adoption and to continue raising gender issues in periodic reviews in the meantime. In order to assist Gaer, Copelon and her students at the CUNY Clinic reviewed the CAT's concluding observations and drew a chart of the gender issues discussed in them, producing a draft general comment on the basis of this information.

At the same time, in reaction to US anti-terrorism practices in the aftermath of 9/ 11, Spanish CAT member Fernando Marino Menendez prepared his own draft general comment, insisting on the absolute character of the prohibition of torture. Gaer and the CUNY Clinic's staff surmised that Marino Menendez's draft would be given precedence and that, due to a lack of time and resources, it would not be possible to publish a general comment on gender in the near future. They therefore decided to integrate gender issues in his draft. Copelon and the CUNY Clinic drafted an alternative, consolidated draft, of which the revised objective was to elaborate on the nature of states' obligations under Article 2 of the Convention against Torture, which states the principles of the prohibition of torture. Gaer brought this draft before the committee in late 2005, and it was discussed in 2006 and 2007, by which time Mavrommatis had been elected chair. ${ }^{18}$

The records of meetings show that, even by then, not all CAT members saw domestic violence as fitting squarely within the CAT's mandate: Chinese expert Wang Xuexian, arguing against recognizing a state obligation to compensate CIDT, pointed out that "[t]here was no precise definition of ill-treatment, and the term could cover virtually anything, domestic violence for example; how could a State possibly be bound to investigate every minor violent incident arising between individuals and compensate every victim?" (CAT 2008a, para. 23). Nevertheless, by 2006, there was little resistance among the CAT experts. A revised draft was circulated for comment by states, NGOs, UN agencies, and national human rights organizations (Gaer 2007, 189). ${ }^{19}$ A few

16. Personal communication with Gaer, April 9, 2020.

17. General Comment no. 2.

18. Personal communication with Gaer, April 9, 2020.

19. These comments, though consolidated in official UN documents, are not publicly available. 
states, among them Switzerland and Poland, expressed concerned that responsibility would be imposed too easily on states for acts of domestic violence beyond their control, a concern that also pervades Xuexian's comment quoted earlier. Yet other states praised the committee for discussing domestic violence, as did Amnesty International and Copelon, who addressed the committee in November 2007. The paragraph in which domestic violence is mentioned was carefully reworded by the committee so as to clarify that state responsibility is conditioned on state actors knowing or having reasonable grounds to believe that the violence is being committed. ${ }^{20}$

\section{The HRC, 1999-2002}

The HRC was established in 1976 to monitor implementation of the International Covenant on Civil and Political Rights (ICCPR), the principal UN treaty protecting the rights traditionally viewed as core human rights. ${ }^{21}$ The ICCPR provides in Article 7 that "[n]o one shall be subjected to torture or to cruel, inhuman or degrading treatment or punishment." The categorization of domestic violence as torture/CIDT did not require profound changes before the HRC. The ICCPR does not define torture or CIDT, and the HRC has refrained from articulating a clear basis for distinguishing between them (Rodley 2002, 482). In 1982, the HRC's General Comment no. 7 clarified that states are responsible for the ultra vires actions of government officials. ${ }^{22}$ This general comment was replaced in 1992 by General Comment no. 20, which indicates that states bear responsibility under Article 7 when the acts are inflicted by persons acting in their private capacity. ${ }^{23}$ The HRC clarified in General Comment no. 31 in 2004 that states bear responsibility for failing to exercise due diligence in preventing and addressing human rights abuses committed by private persons. ${ }^{24}$ Although General Comment no. 31 is not gender specific, it states that it should be read together with General Comments no. 18 and 28 concerning non-discrimination, the latter of which, adopted in 2000, states that "[to] assess compliance with article 7 of the Covenant ... the Committee needs to be provided information on national laws and practice with regard to domestic and other types of violence against women, including rape." 25

Since 1993, domestic violence had been discussed in the HRC's concluding observations in paragraphs concerning women's rights, typically focused on equality. Until 1998, the HRC's concluding observations were not organized by article. After the observations became more systematically organized, they began in 1999 to discuss domestic violence and the broader category of violence against women in relation to torture or

20. Personal communication with Gaer, April 9, 2020; personal communication with former CAT member, April 29, 2020.

21. International Covenant on Civil and Political Rights, December 16, 1966, 999 UNTS 171 (ICCPR).

22. ICCPR General Comment no. 7: Article 7 (Prohibition of Torture or Cruel, Inhuman or Degrading Treatment or Punishment), Doc. HRI/GEN/1/Rev.9 (1982).

23. HRC General Comment no. 20: Article 7 (Prohibition of Torture, or Other Cruel, Inhuman or Degrading Treatment or Punishment), Doc. HRI/GEN/1/Rev.9 (1992).

24. HRC General Comment no. 31 [80]: The Nature of the General Legal Obligation Imposed on States Parties to the Covenant, Doc. CCPR/C/21/Rev.1/Add. 1326 (2004).

25. ICCPR General Comment no. 28: Article 3 (Equality of Rights between Men and Women), Doc. CCPR/C/21/Rev.1/Add.10 (2000), para. 11. 
CIDT. By 2002, the categorization of domestic violence as an issue related to Article 7 of the ICCPR had become routine. In addition, the HRC appears to have set a broader scope of state responsibility than the CAT since it does not require actual knowledge on the part of the state authorities that domestic violence is being committed if they failed to enact measures of prevention such as legislation (Edwards 2006, 374).

The HRC's long-standing recognition of state responsibility for the acts of private actors undoubtedly offered a favorable context for the recognition of domestic violence as torture/CIDT. So did calls to treaty bodies from other UN agencies and conferences to treaty bodies to give greater attention to gender issues and to violence against women (UN Secretary General 1998; Evatt 2002, 4-5). Nevertheless, the link between domestic violence and torture/CIDT was not inevitable. In lists of questions sent to states in preparation for their periodic review in the 1990s, domestic violence appeared in connection with Articles 3 (equality between men and women), 23 (equality between men and women in marriage), and 26 (equality before the law) of the ICCPR, where it could have remained.

Yet, in 1999, a linkage of domestic violence to Article 7 was made in the concluding observations to Romania and Morocco, and this link has been maintained since that time. At the meetings with state delegations preceding those concluding observations, the Chilean jurist Cecilia Medina Quiroga; Elizabeth Evatt, former chief justice of the Family Court of Australia, who had chaired CEDAW before joining the HRC; and the late P. N. Bhagwati, former chief justice of India, who was known for his progressive views, prodded states about domestic violence, without mentioning Article 7 . In the concluding observations prepared by the secretariat of the committee together with these experts, a reference to Article 7 was added to the discussion of domestic violence. Then, in 2000, questions about domestic violence, linked to Article 7, began to appear in the lists of issues sent by the Secretariat to states. Furthermore, Medina Quiroga, who was elected chair of the HRC in 1999, drafted General Comment no. 28, which was devoted to the equality of rights between men and women, in which states are requested to provide information about domestic violence in order to assist the committee's monitoring of their Article 7 obligations (Evatt 2002). ${ }^{26}$ As with the CAT, the norm change was institutionalized through a feminist committee member's activism and the Secretariat drafting increasingly standardized documents.

However, if the pattern of norm change is similar to that of the CAT, the shorter time frame and the less stringent conditions for recognizing state responsibility are noteworthy. What can explain these differences? Contrary to Gaer's experience with the CAT, feminist HRC members encountered no resistance from other committee members, as is clear from the records of the sessions at which the relevant articles of General Comment no. 28 were adopted without disagreement. This lack of resistance can be explained, first, by the composition of the committee. Elizabeth Evatt $(2002,5)$ credits the 1994 elections to the eighteen-member committee of "five new progressive minded members" for helping integrate women's concerns. The fact that, unlike the CAT, the $\mathrm{HRC}$ is not specialized in torture/CIDT but, rather, mandated to address a broad range of issues including equality, explains the appointment of experts specializing in women's rights. The formal inclusion of gender equality in the committee's mandate, and of

26. ICCPR General Comment no. 28. 
women's rights experts among the personnel, made the committee's discussion of gender issues uncontroversial. ${ }^{27}$

Moreover, the committee's practice of treating Article 7 violations holistically, without distinguishing between torture and CIDT, without precisely defining either category and without assigning torture a special stigma, facilitated the introduction of new forms of violence in the purview of that article. As recounted by a member of the HRC at the time, "[n]obody asked the question, are we talking about torture? Are we talking about cruel punishment or inhumane treatment? Or whatever it happens to be because nobody thought it was relevant and we didn't have to be specific. We were saying to states you better address this question, otherwise you're violating article 7 . We don't have to tell you whether it's torture or not." 28 In addition, for this former member of the HRC, the condemnation of domestic violence had broad resonance among states and did not trigger claims of cultural relativism on their part. Finally, it should be noted that states were not given an opportunity to comment on General Comment no. 28, which was drafted at a time when general comments were issued by committees without the extensive public deliberation that accompanies the process in more recent years.

\section{The IACHR and IACtHR, 1996-2011}

The American Convention on Human Rights (American Convention), which entered into force in 1978, assigns the monitoring of states' compliance with the convention to the IACHR and IACtHR. ${ }^{29}$ Although the IACHR sends the court only fourteen cases per year on average, the IACtHR has developed a progressive and distinctive jurisprudence (Antkowiak and Gonza 2017, 10). In particular, the IACtHR's first judgment on the merits, Velásquez-Rodriguez, is a landmark case in the establishment of positive obligations on states. ${ }^{30}$ The inter-American system thus provided a favorable doctrinal terrain for the recognition of state responsibility for domestic violence.

Latin American women's movements have also forcefully pushed for the recognition of private violence against women as a human rights violation. In fact, Copelon (2007, 232-33) traced her interest in framing domestic violence as torture to a workshop of the Latin American and Caribbean Feminist Meeting in 1994, where Latin American feminists familiar with the repressive practices under dictatorships saw parallels with domestic violence. Hence, as early as 1994, American states adopted the Belém do Pará Convention, which was the first treaty to specifically establish that private violence against women constitutes a violation of human rights. Article 4 of the Belém do Pará Convention recognizes women's right to physical, mental, and moral integrity and to be free from torture.

Moreover, the definition of torture in the inter-American system is very broad. Because Article 5 of the American Convention, prohibiting torture and ill-treatment, does not define these terms, the IACtHR has often referred to the 1985 Inter-American

27. Personal communication with former HRC member, interview via Zoom, May 24, 2020.

28. Personal communication with former HRC member, May 24, 2020.

29. American Convention on Human Rights, 21 November 1969, 1144 UNTS 123.

30. IACtHR, Velásquez-Rodriguez. 
Convention to Prevent and Punish Torture (American Torture Convention), which defines torture in Article 2 as "any act intentionally performed whereby physical or mental pain or suffering is inflicted on a person for purposes of criminal investigation, as a means of intimidation, as personal punishment, as a preventive measure, as a penalty, or for any other purpose. ${ }^{31}$ Torture shall also be understood to be the use of methods upon a person intended to obliterate the personality of the victim or to diminish his physical or mental capacities, even if they do not cause physical pain or mental anguish" (Antkowiak and Gonza 2017, 108-10). While this definition does not require state involvement, Article 3 of the American Torture Convention limits the crime of torture to public servants or employees or people acting at the instigation of such individuals.

The IACtHR and IACHR established state responsibility for failing to prevent and/or investigate domestic violence in a few rulings between 2000 and 2011. These landmark cases are the result of strenuous activism on the part of coalitions of victims of domestic violence, grassroots organizations, and NGOs from North and South America who were well versed in international law. In 1996, the Center for Justice and International Law (CEJIL), the Latin American and Caribbean Committee for the Defense of Women's Rights (CLADEM), and the grassroots União de Mulheres de São Paulo brought a case against Brazil on behalf of the family of Márcia Leopoldi who had been assassinated by her ex-boyfriend. According to Cecília MacDowell Santos (2018, 203-5), CEJIL, a regional organization and repeat player within the inter-American system, saw the case as an opportunity to expand its activities to women's rights and to set a precedent that would allow it to bring pressure on members of the Organization of American States to respect those rights. CLADEM, a regional network of feminist legal experts, saw in the case an opportunity to test the application of the Belém do Pará Convention while pressuring the Brazilian state to set up a domestic violence policy. The case did not produce any ruling, however, as Leopoldi's ex-boyfriend was arrested, and the IACHR, CLADEM, and CEJIL considered the case resolved (205).

In 1998, CEJIL, in search of further strategic cases on violence against women, contacted Maria da Penha, a Brazilian pharmacist whose husband had attempted to murder her, leaving her paraplegic (MacDowell Santos 2018, 207). CLADEM, CEJIL, and da Penha petitioned the IACHR, invoking a violation of Article 7 of the Belém do Pará Convention, which sets out the state's due diligence obligations, in relation to the subparagraphs of Article 4 that protect women's rights to physical and mental integrity as well as to be free from torture. The IACHR held Brazil responsible for these violations, linking for the first time in the inter-American system domestic violence with torture/CIDT. ${ }^{32}$

The ruling in Maria da Penhav. Brazil made this link within the context of the Belém do Pará Convention, which explicitly recognized domestic violence as a human rights violation. A decade later, in 2009, the IACtHR held Mexico responsible, under, inter alia, Article 5(2) of the American Convention prohibiting torture and CIDT, for failing to prevent and properly investigate the abuse and murder of eight girls whose

31. Inter-American Convention to Prevent and Punish Torture, December 9, 1985, OAS Treaty Series no. 67.

32. IACtHR, Maria da Penha v. Brazil, Case 12.051 (April 16, 2001), paras. 2, 58. 
bodies were found in a cotton field near Ciudad Juarez, in a case commonly known as Cotton Field. ${ }^{33}$ However, it did not expressly classify the abuses as torture, an omission that Medina Quiroga, who was by then a judge at the court, explained as the possible result of a mistaken belief by her colleagues "that a State could not be found responsible for an act of torture if there was no evidence that it had been perpetrated by State agents or that it had been carried out when a public servant or employee." ${ }^{34}$

The petition had been filed in 2002 by Sonia Torres Hernández, Alfredo Limas Hernández, and their colleagues at the Red Ciudadana de No Violencia y por la Dignidad Humana (Red). Torres Hernández had fifteen years of experience organizing in Ciudad Juarez and attending to women's needs. Profoundly shocked by the discovery of the bodies, she and members of other grassroots organizations in Ciudad Juarez formed the Red. ${ }^{35}$ Disappointed with the response of the federal government, the Red considered turning to the inter-American system, with which it had no experience. Before doing so, the Red members launched a broad public consultation to ensure that they had the community's support. They also approached the victims' mothers, took their testimonies, and worked for years to help them in their struggle for justice. The petition lingered in the IACHR for three years before being declared admissible in 2005, with the mothers insisting, even after the government had made a settlement offer, on pursuing it before the court. ${ }^{36}$

The IACHR (which brings cases to the court) had not invoked Article 5(2) of the American Convention in relation to the victims, only in relation to their next of kin, to account for their suffering as a result of the murders. It was Torres Hernández and Limas Hernández who added the claim of a violation of the murdered women's right to humane treatment, explaining in their brief that this was important in order to clarify that the state was responsible not just for the killing but also from the moment the women were deprived of their liberty. Limas Hernández saw the addition of this claim as the Red's central contribution to the legal arguments. He explained that the violation of the right to humane treatment appeared to his companions and himself as the best way to reflect the broad extent of the violations, including captivity and sexual violence, and to express the elements of class, gender, and age in the violence: "The right to integrity, it was not only having lost your life, but everything that had happened and that had to do with being girls and being poor." ${ }^{37}$ In addition, for Torres Hernández, it was only natural to argue torture, given the horrible marks on the bodies of the victims. ${ }^{38}$

By the time the case reached the court, the Red had been joined by CLADEM and the National Association of Democratic Lawyers (ANAD). The grassroots organizations that had initiated the case succeeded in defeating ANAD and CLADEM's persistent attempts to take over legal representation and were able to do so thanks to the legal advice they received from experts in the inter-American system-in particular, Ariel Dulitsky, who was the former co-director of CEJIL, among other activities.

33. IACtHR, González et al. v. Mexico (Cotton Field), Case 12.626 (November 16, 2009).

34. IACtHR, Cotton Field, Concurring Opinion of Judge Cecilia Medina Quiroga, para. 9.

35. Personal communication with Sonia J. Torres Hernández, interview via Zoom, June 4, 2020.

36. Personal communication with Torres Hernández, June 4, 2020.

37. Personal communication with Alfredo Limas Hernández, interview via Zoom, June 18, 2020.

38. Personal communication with Torres Hernández, June 4, 2020. 
Despite conflicts over control, the various organizations and the mothers had overlapping objectives: having the mothers' version of the facts acknowledged, shedding light on the failures of the local and federal government, and pressuring the state to properly investigate the incident and repair the damage that had been done. ${ }^{39}$ The case drew much international interest, and thirteen amicus briefs were submitted by international advocacy groups. Copelon testified at the hearing as an expert witness, explaining to the court the specificities of the violence against the women and how a gender perspective can be integrated in states' due diligence obligations.

To support its reasoning in relation to Article 5(2) of the American Convention prohibiting inhumane treatment, the court referred to the Belém do Pará Convention, the ruling in Maria da Penha v. Brazil, General Recommendation no. 19 of the CEDAW, and other international documents providing a state obligation to prevent and address violence against women by private actors. It also referred to its own case law on the obligation to conduct effective investigations. ${ }^{40}$ It further found that Mexico had violated its obligation not to discriminate when fulfilling its due diligence obligations, referring to the ECtHR's ruling in Opuz v. Turkey. ${ }^{41}$

Two years later, in Jessica Lenahan (Gonzales) v. United States, the IACHR found the United States responsible for failing to prevent the murder of the petitioner's three daughters by her ex-husband. ${ }^{42}$ The case was led by Caroline Bettinger-López, who was at the American Civil Liberties Union and later at the Columbia Law School Human Rights Clinic. Like in Cotton Field, the case reached the inter-American system thanks to the insistence of the mother of the victims, following a loss before the Supreme Court of the United States. Once the petition was filed, the IACHR demonstrated enthusiasm for an opportunity to hold the United States accountable, pushing the case along swiftly. ${ }^{43}$ However, contrary to the briefs submitted by the petitioner and the third-party interveners, including Copelon (whom Bettinger-López describes as a "mentor"), the IACHR did not find a violation of the right to humane treatment, focusing instead on the rights to life and equality. For the petitioners, however, the principal objectives were met: holding the United States to international standards while strengthening the international jurisprudence on states' positive obligations in the face of domestic violence. $^{44}$

\section{The ECtHR, 2009-13}

With over twenty-one thousand judgments concerning a broad range of civil and political rights, the ECtHR's case law enjoys authority well beyond the forty-seven states that are party to the European Convention on Human Rights (ECHR). ${ }^{45}$ The

39. Personal communication with Torres Hernández, June 4, 2020.

40. IACtHR, Cotton Field, para. 246. 2009).

41. IACtHR, Cotton Field, para. 396; ECtHR, Opuz v. Turkey, Application no. 33401/02 (June 9,

42. IACtHR, Jessica Lenahan (Gonzales) v. United States of America, Case 12.626 (July 21, 2011).

43. Personal communication with Caroline Bettinger-López, interview via Zoom, May 27, 2020.

44. Personal communication with Bettinger-López, May 27, 2020.

45. Convention for the Protection of Human Rights and Fundamental Freedoms, November 4, 1950, 213 UNTS 221 (ECHR). 
court has generally produced expansive interpretations of rights through an evolutive approach to interpretation (Sjöholm 2017, 134). In addition, as part of its bid to interpret the ECHR so as to make rights effective, the ECtHR has recognized positive obligations since the 1970s, an approach that has brought with it openness to dealing with violence by private parties (Yildiz 2016, 8; in reference to Krahenmann 2012, 3). While the ECHR defines neither torture nor ill-treatment, which are both prohibited in Article 3, the two have been distinguished in the European human rights jurisprudence since the 1960s-ill-treatment being defined as "at least such treatment as deliberately causes severe suffering, mental or physical" and torture described as an aggravated form of ill-treatment, committed for a specific purpose. ${ }^{46}$ In any event, for Article 3 to be applicable, the ill-treatment must reach a minimum level of severity, of which the assessment depends on the circumstances of the case. ${ }^{47}$

Two principal cases, Opuz v Turkey in 2009 and Valiuliené v. Lithuania in 2013, established that states can be held responsible under Article 3 of the ECHR for failing to prevent or address domestic violence against women. ${ }^{48}$ In Opuz, Turkey was held responsible under Article 2, which protects the right to life, in relation to the murder of Nahide Opuz's mother, and Article 3 jointly with Article 14, which prohibits discrimination for failing to protect the applicant and her mother from repeated assaults from their spouses. Yet, after Opuz, the court continued to consider responsibility for domestic violence under Article 8, which protects family life and privacy, opening the possibility that the Article 3 holding in Opuz was linked to the particularly horrific nature of the violence. In Valiuliené, however, the court insisted that domestic violence be addressed under Article 3 and not Article 8 as suggested by the respondent state. Lithuania was held responsible for failing to diligently prosecute the applicant's former partner who had beaten her on five occasions. The court rejected the state's contention that the case should be distinguished from Opuz as Loreta Valiuliené, an educated woman, was not in a situation of special vulnerability, following the court's jurisprudence that, when assessing states' positive obligations under Article 3, "children and other vulnerable individuals" were particularly entitled to state protection. While the court was "unable to fully share the applicant's view that she, as a woman, by default fell into the category of vulnerable persons," it held that "the ill-treatment of the applicant, which on five occasions caused her physical injuries, combined with her feelings of fear and helplessness, was sufficiently serious to reach the level of severity under of Article 3 of the Convention." 49 Since then, the dozen or so decisions concerning domestic violence have analyzed states' obligations under Article 3.

As at the HRC, feminist advocacy before the ECtHR was built on a long-standing recognition of positive obligations in relation to the article prohibiting torture. Moreover, similarly to the "encouraging" state officials occasionally appearing before the CAT, the norm change was the result of partnerships between norm entrepreneurs and advocates seeking international condemnations of the state in order to mobilize such condemnations locally. Yet, unlike the almost imperceptible shift in the HRC's

46. European Commission of Human Rights, The Greek Case, Application no. 4448/70 (April 10, 1970), 186.

47. ECtHR, Ireland v. United Kingdom, Application no. 5310/71 (December 13, 1977).

48. ECtHR, Opuz; ECtHR, Valiuliené v. Lithuania, Application no. 33234/07 (March 26, 2013).

49. ECtHR, Valiuliené, paras. 69, 70. 
documents from articles on equality to the article on torture, the change before the ECtHR occurred through judicial rulings and was therefore highly visible, triggering state resistance as well as the resistance of some judges. This change also occurred against the background of the court attempting to sail its well-known, uneasy course between protecting rights and avoiding state criticism that it was infringing on individual state sovereignty. As a result, the inclusion of domestic violence in the purview of Article 3 did not go as far as some proponents wished. In a concurring opinion in Valiuliené, Judge Pinto de Albuquerque lamented that the majority applied Article 3 based on a factual assessment of the severity of the violence suffered by the applicant, when, in his view, given "the factual inequalities between women and men and the way they impact on women's lives ... it is self-evident that the very act of domestic violence has an inherent humiliating and debasing character for the victim." 50

The applicants in Opuz and Valiuliené were represented by local human rights lawyers who not only sought justice for their clients but also aimed to pressure their countries to combat domestic violence. "I want to see an end to violence against women and I want the state, the judiciary and the police to take it seriously," Turkish lawyer Mesut Bestas was reported as saying on behalf of his client Nahide Opuz (quoted in Seibert 2009). In fact, the very filing of the claim before the ECtHR created pressure on the Turkish government, which had begun negotiating entry into the European Union in 2005, and the country struggled to preserve a positive international image when a disproportionate number of ECtHR rulings pronounced it in violation of the ECHR. The filing led a Turkish Ministry of Justice official to pressure the local prosecution service to resume the proceedings against the applicant's husband. ${ }^{51}$

Similarly, Jurate Guzeviciute, the main lawyer working on the Valiuliené case on behalf of the Lithuanian Human Rights Monitoring Institute (HRMI), reached out to the applicant after hearing about her case in the media, in a bid to use the ECtHR case to highlight the national authorities' lack of implementation of recent domestic violence legislation. Once the HRMI took over the case, the complaint was amended to include an allegation of the violation of Article 3 of the ECHR, which Guzeviciute saw as making a stronger statement than other articles about the severity of the Lithuanian government's failure to act. The lawyers at HRMI were also inspired by the court itself, which in communicating the case to the respondent state had asked it to address the possibility that the applicant's treatment violated Article $3 .^{52}$

In Opuz, the claims were strengthened by the submission of a third-party brief by Interights, a London-based human rights organization, represented by Andrea Coomber. The case was brought to Coomber's attention by the ECtHR Registry (the body providing legal and administrative support to the court), which pointed out to her that the case raised important issues and highlighted the parts of the claim that could benefit from further argumentation. ${ }^{53}$ Interights intervened in the case "to show what the obligations of the state were when it came to domestic violence" (Coomber 2018). Coomber and her colleagues hoped to have domestic violence

50. ECtHR, Valiuliené, 29-30.

51. ECtHR, Opuz, para. 62.

52. Personal communication with Jurate Guzeviciute, interview via Zoom, May 6, 2020.

53. Personal communication with Coomber, May 20, 2020. 
categorized as an Article 3 violation, a framing she believed would emphasize the gravity of the practice..$^{54}$ However, in Interights's written and oral submissions, the primary lens for analyzing the case was discrimination. Article 14 of the ECHR, which prohibits discrimination, can be invoked only in combination with another article of the convention. ${ }^{55}$ Article 3 , which prohibits torture/CIDT, provided such a "hook" with respect to the applicant's treatment. The Interights's brief reviewed recent developments in international law-in particular, the ruling in Maria da Penha v. Brazil and CEDAW's publications-to support its contention that the ECtHR should adopt a standard of due diligence requiring swift action by states in the face of domestic violence.

The court invited Interights to address it at the oral hearing, a rare occurrence at the time. Coomber reports finding a sympathetic ear in the female Swedish judge. At the hearing, she extensively discussed the jurisprudence of the inter-American system and other human rights bodies linking domestic violence and discrimination. In doing so, she aimed to suggest that the court was at risk of losing its status as a leading human rights body. Noting that the panel was not staffed by particularly progressive judges, she credits this appeal to the court's standing, as well as the "extreme fact pattern" of the case, for the outcome-a unanimous finding that Articles 2, 3, and 14 of the ECHR had been violated..$^{56}$ Whether or not the court was in fact concerned with its standing, by invoking comparative human rights jurisprudence, Coomber offered the court sources with which to buttress the legitimacy of a favorable ruling, whether legally (Seibert-Fohr 2015) or morally (McCrudden 2007, 376).

In Opuz and Valiuliené, the claimants and court also had a strong and clear doctrinal basis in the ECtHR's jurisprudence itself: between 1998 and 2002, children's rights advocates from the United Kingdom (UK) had succeeded in obtaining ECtHR rulings that the state was responsible under Article 3 for failure to protect children from violence at home. This jurisprudence was inaugurated with A. v. United Kingdom, in which the court ruled that Article 3 had been violated in a case of caning, as English law did not provide sufficient protection to children since the defense of "reasonable punishment" was available to the claimant's stepfather against the charge of assault. ${ }^{57}$ The case was brought by several renowned English children's rights advocates, including Allan Levy, and, in the arguments, both the now-defunct European Commission on Human Rights and the court relied on the Convention on the Rights of the Child and the pronouncements of the Committee on the Rights of the Child (CRC) to find the UK in violation of Article 3 of the ECHR. ${ }^{58}$ Before the court, the UK government conceded that Article 3 had been violated, and it "asked the Court to confine itself to considering the facts of the case without making any general statement about the corporal punishment of children." ${ }^{59}$ It seems that, in conceding the Article 3 violation, the UK government attempted to avoid a broader ruling that

54. Personal communication with Andrea Coomber, interview via Zoom, May 20, 2020.

55. Turkey has not ratified Protocol no. 12 to the ECHR, which creates a standalone prohibition of discrimination.

56. Personal communication with Coomber, May 20, 2020.

57. ECtHR, A. v. United Kingdom, Application no. 35373/97 (December 17, 2002).

58. Convention on the Rights of Children, November 20, 1989, 1577 UNTS 3.

59. ECtHR, A., para. 18. 
would have outlawed corporal punishment of children entirely. Indeed, after the CRC had voiced concerns about corporal punishment in the UK in 1995, some individuals in the British media expressed worry about parents losing the "right to smack" their children. After A. v. United Kingdom, the government reassured the public that it had no intention to abolish corporal punishment (Foster and Ginell 1999, 190).

A. v. United Kingdom can therefore be seen as a compromise. The court ruled that states could be responsible under Article 3 for failing to protect children from corporal punishment, but its ruling was dependent on the severity of the harm suffered by the child in the particular circumstances, falling short of a categorical condemnation of corporal punishment (Foster and Ginell 1999, 190). The same approach of conditioning the applicability of Article 3 on the severity of the treatment suffered by the applicant in the case was followed in Z. and Others $v$. United Kingdom in 2001 and in E. and Others $v$. United Kingdom in 2002, cases concerning severe neglect of children by their parents and sexual and emotional abuse of children by their stepfather, respectively. ${ }^{60} \mathrm{~A} ., \mathrm{Z}$., and E. would all serve as precedent in Opuz, Valiuliené, and their progeny, where they were invariably referenced.

Where did states stand in Opuz and Valiuliené? The Turkish government in Opuz did not argue that Article 3 was inapplicable to the case, arguing instead that the applicant and her mother's withdrawal of their complaints to the police had prevented authorities from pursuing proceedings. ${ }^{61}$ In Valiuliené, in contrast, Lithuania conceded that it had violated the right to privacy under Article 8, insisting in its written submissions that the violence did not reach the level of severity required for Article 3 and, generally, that domestic violence cases could be litigated under other articles of the ECHR. This concession offered the court an easy way to rule in the applicant's favor, especially since, once an article of the convention has been found to be violated, the court typically declares it unnecessary to examine additional articles. Nevertheless, the court chose to categorize the acts as an Article 3 violation as argued by the plaintiff.

\section{TOWARDS AN ENRICHED UNDERSTANDING OF EVERYDAY LAWMAKING IN IHRL}

This part draws out the actors, processes, opportunities, and constraints of everyday lawmaking in IHRL. The stories told above reflect many insights of both constructivist and experimentalist accounts. As predicted by constructivism, the change was led by feminist advocates consciously strategizing to change the law, collaborating amongst themselves, and leveraging institutional opportunities. In line with experimentalism, the process of norm evolution was incremental and recursive. Yet the stories also expose the significance of legal features and exercises of power that neither constructivists nor experimentalists consider seriously. Taken together, they produce a more nuanced assessment of lawmaking in IHRL as a process both emancipatory and hegemonic.

60. ECtHR, Z. and Others v. United Kingdom, Application no. 29392/95 (May 10, 2001); ECtHR, E. and Others v. United Kingdom, Application no. 33218/96 (November 26, 2002).

61. ECtHR, Opuz, para. 156. 


\section{Actors}

As predicted by the norm life cycle model, norm entrepreneurs in each institution, who were committed to promoting awareness of the gravity of domestic violence and pressuring states to act against it, consciously strove to frame it as falling in the category of torture/CIDT. These norm entrepreneurs could be legal experts and judges (Gaer, Evatt, Medina, Pinto de Albuquerque) or civil society activists (Copelon, Coomber). Copelon, in particular, was a central player not only in calling for the norm change from an academic platform but also in acting before the CAT and the interAmerican institutions and advising other activists. Norm entrepreneurs partnered with each other, with feminist and other human rights activists focused on mobilizing international rulings for local purposes, and with sympathizers with overlapping interests (such as Mavrommatis). In line with the literature pointing to states' strategic, superficial commitment to human rights norms (Risse, Ropp, and Sikkink 1999; Hacker 2015), states occasionally acquiesced or even actively contributed to the norm change out of short-term interest, such as Argentina and Venezuela offering information on domestic violence before the CAT or the UK conceding to the applicability of Article 3 in child abuse cases in order to obtain a narrow judgment.

While offering examples of collaboration and of victim-centered advocacy ( $\mathrm{Da}$ Penha, Cotton Field, and Lenahan), the findings also illustrate the unequal power relations among norm entrepreneurs from civil society (Carpenter 2011; MacDowell Santos 2018): in Opuz, the ECtHR's Registry appealed to Interights, a Western organization affiliated with the global legal elite, to bolster the Turkish lawyer's legal argumentation; in Cotton Field, the grassroots organizations had to fight tooth and nail to retain control over the case. This suggests that the experimentalist emphasis on the participation of actors from the periphery should be tempered by an understanding that such participation is unequal. Moreover, attention should be given to the significant-and, currently, hidden-power of junior bureaucrats to raise issues (ECtHR's Registry in Opuz) and institutionalize changes (UN Secretariat with respect to the CAT and the HRC).

In addition to norm entrepreneurs, their sympathizers, state actors with short-term interests, and bureaucrats, some of the landmark cases, such as Cotton Field and Valiuliené, were pushed by victims, grassroots organizations, and strategic litigators with little interest in international norm entrepreneurship, pursuing primarily personal or national goals. Norm entrepreneurs thus share control of lawmaking with a wide range of actors.

\section{Process}

In this case, norm change took a slower, incremental, and more haphazard trajectory than suggested by the normal life cycle. There is no "cascade" moment at which a critical mass of persuaded states can be pointed to or at which institutions can be seen to firmly get on board the norm entrepreneurs' project, even considering each body in isolation. Rather, activists carefully established a series of incremental steps before each institution: in the HRC, domestic violence was first discussed in relation to equality, before a shift to Article 7 was made in the concluding observations and in General 
Comment no. 28. Gaer and Mavrommatis built a record at the CAT in concluding observations that served as a basis for drafting General Comment no. 2. Before the $\mathrm{HRC}$ and the inter-American system, the framing of domestic violence as CIDT was built on the general recognition of state responsibility for private actors and on the specialized Belém do Pará Convention. Children's rights activists obtained victories that lay the groundwork for women's rights activists a decade later before the ECtHR. The landmark case of Opuz was not sufficient to institutionalize the change, since domestic violence was still not routinely litigated under Article 3 of the ECHR until 2013, and it took a case of more banal domestic violence to firmly establish the relevance of that article.

While these incremental expansions were effected through standard legal techniques of analogical reasoning and the invocation of precedent, the actors can be seen from a strategic perspective to be "grafting" their claims onto previous successful ones. However, contrary to international relations scholars' understanding of grafting as the general framing of a new issue in relation to a previous one, this case shows multiple instances of "micro-grafting," whereby actors incrementally expanded the meaning of the norm, each building on a prior specific interpretation: domestic violence was grafted onto prohibited acts as diverse as rape in prison, child abuse, and paramilitary violence. Some of this grafting involved the same norm entrepreneurs in various stages, such as Gaer's establishment of a record in the concluding observations on which to graft the general comment she herself drafted. In other instances, it was uncoordinated, such as the grafting of women's rights advocacy on children's rights successes and of advocacy for the recognition of banal domestic violence (Valiuliené) on the successes of advocacy for the recognition of horrific domestic violence (Opuz). Thus, instead of a linear process of norm change as a result of successful formations of activist networks, we see here an incremental, recursive, and uncoordinated process of norm evolution.

\section{Opportunities and Constraints}

The law and procedure of IHRL have functioned not only as opportunities to be mobilized but also as constraints on norm development. The norm entrepreneurs have leveraged many political opportunity structures: the UN and regional organizations' focus on gender-based violence; the urgency created by the post-9/11 era for the CAT to issue a general comment clarifying states' obligations; and the presence of feminist and progressive experts and judges at the HRC, the ECtHR, the IACtHR, and the IACHR. They also leveraged law, procedural rules, and bureaucratic practices, including rules of procedure giving NGOs access to treaty body proceedings and offering them the ability to represent petitioners and submit third-party briefs as well as the standardization of treaty body working methods that led to the recurrent appearance of domestic violence in questions sent to states and in concluding observations. These practices also include the broad mandates of generalist bodies, where domestic violence could have more easily made its first steps on the stage in connection with articles unrelated to torture than in the CAT.

As is to be expected in legal advocacy, when grafting, the norm entrepreneurs took advantage of the "fit" of their claims with precedent, such as rulings recognizing child 
abuse as inhumane treatment, the HRC's recognition of state responsibility for violence by private actors, or the less controversial recognition in the CAT of sexual violence in prison. The case thus illustrates the path dependence that scholars have identified in international advocacy, where existing issues shape the emergence of new issues (Carpenter 2010, 237). Yet this study shows that it is not only that existing issues (in this case, private actor violence or child abuse) provide an advantage to new issues that resonate with them (domestic violence) but also that the analytical framework for addressing existing issues is carried over to the new ones. Thus, the formulation of states' positive obligations in relation to the prohibition of torture as primarily consisting of diligent criminal prosecution has carried over to the treatment of domestic violence. So did the ECtHR's case-by-case analysis of whether an applicant's claim reaches the level of severity to make Article 3 applicable, at the expense of a general characterization of domestic violence as ill-treatment. Viewing norm change in IHRL not only as the appearance of new issues on the agenda of the international community but also as grafting legal doctrine allows one to identify with more precision how path dependence limits the ways in which issues are discussed in IHRL. While, in more recent years, some actors operating within IHRL have focused on structural remedies other than criminal prosecution when addressing domestic violence as torture, these efforts have remained peripheral (Davidson 2019, 131-33).

The inclusion of domestic violence was likely facilitated by the abstractness of the formulations of torture and CIDT before the HRC, in line with the experimentalist account. With respect to other institutions, when Copelon and other feminist advocates argued that domestic violence unproblematically fit the existing concept of torture, they can be seen as invoking an abstract, broader category of torture. However, from a doctrinal perspective, the CAT and the inter-American system operated with rather specific definitions of torture. The key creative process before those institutions is therefore not the specification of abstract norms. Instead, the case highlights the hardening of soft law and the consolidation of interpretations across a fragmented field. I discuss each of these in turn.

While some states expressed surprise at being questioned by the CAT about domestic violence, they did not mount a serious opposition. After all, in periodic reviews, they were not taking part in a judicial proceeding. For the same reason, in reviews before the HRC, states were not likely to argue about the exact article under which domestic violence was to be discussed-Article 3 or 7 of the ICCPR. Yet these periodic reviews, and the standardized list of questions and concluding observations they produced, established the categorization of domestic violence as torture/CIDT before these bodies, justifying the general comments that further cemented the norm change. The pronouncements of treaty bodies also assisted in the consolidation of the norm in the regional courts. While neither the IACHR, the IACtHR, nor the ECtHR extensively cited from the CAT and the HRC in the rulings discussed above, they drew heavily on the publications of the CRC in the child advocacy cases and even more on the publications of CEDAW (the ECtHR in Opuz, the IACtHR in Cotton Field). Moreover, the litigants and third-party interveners before the regional courts referred extensively to the work of the treaty bodies, including CAT and the HRC. This case reveals a movement within the treaty bodies, and from treaty bodies to regional courts, whereby norms and ideas initially conceived as non-binding are vested 
with increasingly binding meaning. This movement furthers creativity as the initial stages, lacking requirements of legal precision, allow expansive, novel interpretations to take root.

The movement from treaty body to regional court is key to the hardening of soft law. Norms also travel among bodies, not just formally but also through shifts of personnel-Mavrommatis from the HRC to the CAT, Evatt from CEDAW to the HRC, and Medina Quiroga from the HRC to the IACtHR. In each case, these individuals brought to their new position an understanding of the culture and approach to human rights of the previous institution. Here we see the diversity of approaches and foci of attention among institutions in IHRL not as a sign of "hypertrophy" and weakness (Posner 2014, 91-94) but, rather, as an enabler of creativity. It is not only that specialized treaty bodies such as CEDAW and the CRC develop a rich understanding of their areas of expertise, but the jurisprudence of regional bodies also reflects regional historical circumstances. Hence, it is no surprise that the IACtHR was a forerunner in the recognition of state responsibility for private actors in the context of the extensive use of paramilitary groups by states in the Latin America. While these specialized, unique interpretations of rights are produced in each institutional context, they are subsequently circulated to the other bodies within the regime, through personnel shifts and the comparative citations central to judicial legitimacy (Seibert-Fohr 2015). This process of consolidation of a fragmented field is incremental and slow. It nevertheless enables the injection of novel ideas into the system as a whole.

\section{CONCLUSION}

This article has focused on lawmaking at the international level. It has set aside important questions as to how international legal norms are mobilized domestically and how they affect state behavior and people's lives. Research into these questions will be necessary in order to comprehensively evaluate the inclusion of domestic violence as torture/CIDT and, in particular, how emancipatory this normative change is in practice.

This article has argued that everyday lawmaking in IHRL is a complex, incremental process involving a wide range of actors, including activists who graft their claims onto previous activists' successes, leveraging the soft law character and fragmentation of much of the field and negotiating legal outcomes. These findings suggest that IHRL is a site of bounded opportunity for legal change. While structured to enable normative creativity and participation by subordinate actors at the periphery, IHRL also contains hidden sites of power, does not erase inequalities among civil society actors, and strengthens path dependence, even in a case such as this one, where ideologically driven actors have achieved significant norm change.

The present case traces a legal change that occurred within a highly favorable environment, as the norm entrepreneurs built on the mainstreaming of gender issues at the UN. Yet tentative generalizations can be drawn from this case. Many struggles for legal norm change in IHRL are embedded in broader discursive changes similar to gender mainstreaming, such as the recent rise in interest in IHRL for economic inequality and environmental concerns. However, as explained in the second part of this article, this case was chosen not because of its representativeness but, rather, because of its 
strategic value in relation to existing theoretical models. If, in a case such as this one, led by activists building on a profound shift in international discourse, change was incremental and negotiated, then it is highly likely that this will be so in other cases. In areas of IHRL experiencing less transnational advocacy, it is plausible that lawmaking involves even more actors operating in an uncoordinated fashion.

This study is also historically bound. The norm change began in the late 1990s. Until the mid-2000s, NGOs participated less in periodic reviews before treaty bodies, and states did not participate in the elaboration of general comments. In addition, states were probably less aware that concluding observations could ground changes in "hard" law. Norm change in present-day IHRL is therefore likely to be more conflictual, requiring more compromise. This is especially so now that conservative and anti-feminist civil society activists have entered the field (Stoeckl 2016; Dudai 2017).

These findings suggest that both constructivists and experimentalists could benefit from a deeper engagement with the legal-institutional characteristics of IHRL and how these characteristics shape the struggles, negotiations, and overlapping interests among the participants in everyday lawmaking. By paying more attention to law, constructivists will be able to better unearth how power is exercised in IHRL. By paying attention to a broader range of legal features in IHRL, experimentalists will be able to more accurately portray IHRL as a field. Beyond these methodological contributions, the article offers a more nuanced assessment of lawmaking in IHRL. Exposing hidden sites of power and persisting inequalities, it attenuates the experimentalist celebration of IHRL as a participatory field. Emphasizing incrementalism and the variety of participants, it is less optimistic than constructivists about the ability of social movements to transform IHRL.

To confirm these conclusions and refine them, the socio-legal perspective developed in this article should be applied to other cases in IHRL. The minute processtracing methodology developed for this project could also be fruitful to explore norm change in other areas of international law and of law more generally. In particular, by starting from legal data points and tracing backwards the actors involved in producing and pursuing them, rather than starting from a particular social movement or professional body and studying its involvement in legal struggles, this approach avoids privileging one type of actor and one type of factor over others, opening the door to unexpected findings.

\section{REFERENCES}

Alston, Philip. 2013. "Does the Past Matter? On the Origins of Human Rights." Harvard Law Review 126: 2043-82.

Antkowiak, Thomas M., and Alejandra Gonza. 2017. The American Convention on Human Rights: Essential Rights. Oxford: Oxford University Press.

Bob, Clifford. 2011. The International Struggle for New Human Rights. Philadelphia: University of Pennsylvania Press.

Brown, Wendy. 2004. “The Most We Can Hope For ...': Human Rights and the Politics of Fatalism.” South Atlantic Quarterly 103, nos. 2-3: 451-63.

Burgers, Herman J., and Hans Danelius. 1988. The United Nations Convention against Torture: A Handbook on the Convention against Torture and Other Cruel, Inhuman or Degrading Treatment or Punishment. Vol. 84. Leiden: Martinus Nijhoff. 
Carpenter, Charli R. 2010. "Governing the Global Agenda: 'Gatekeepers' and 'Issue Adoption' in Transnational Advocacy Networks." In Who Governs the Globe?, edited by Deborah Avant, Martha Finnemore, and Susan Sell, 202-37. Cambridge, UK: Cambridge University Press.

- 2011. "Vetting the Advocacy Agenda: Network Centrality and the Paradox of Weapons Norms." International Organization 65, no. 1: 69-102.

Chimni, B. S. 2004. "International Institutions Today: An Imperial Global State in the Making." European Journal of International Law 15, no. 1: 1-37.

Cohen, Harlan Grant. 2012. "International Law's Erie Moment.” Michigan Journal of International Law 34: 249-308.

CAT (Committee against Torture). 1997. Convention against Torture and Other Cruel, Inhuman or Degrading Treatment or Punishment 1996: Argentina. Doc. CAT/C/34/Add.5. Geneva: United Nations.

1999. Summary Record of the 370th Meeting. Doc. CAT/C/SR.370. Geneva: United Nations. . 2008a. Summary Record of the First Part (Public) of the 778th Meeting. Doc. CAT/C/SR.778. Geneva: United Nations.

. 2008b. Summary Record of the First Part (Public) of the 784th Meeting. Doc. CAT/C/SR.784. Geneva: United Nations.

CEDAW (Committee on the Elimination of Discrimination against Women). 1992. General Recommendation no. 19. UN Doc. A/47/38. Geneva: United Nations.

Coomber, Andrea. 2018. "Interview by Margot Speed and Ellie Olcott: Andrea Coomber." Cambridge Globalist, January 24. https://cambridgeglobalist.org/?p $=1059$.

Copelon, Rhonda. 1994. "Recognizing the Egregious in the Everyday: Domestic Violence as Torture." Columbia Human Rights Law Review 25: 291-367.

- 2007. "Gender Violence as Torture: The Contribution of CAT General Comment No. 2." New York University Law Review 11: 229-63.

Davidson, Natalie R. 2019. "The Feminist Expansion of the Prohibition of Torture: Towards. PostLiberal International Human Rights Law?" Cornell International Law Journal 25: 109-36.

Davis, Lisa. 2017. "The Gendered Dimensions of Torture: Rape and Other Forms of Gender-Based Violence as Torture under International Law." In Torture and Its Definition in International Law: An Interdisciplinary Approach, edited by Metin Ba囚o囚lu, 315-72. Oxford: Oxford University Press.

De Búrca, Gráinne. 2017. "Human Rights Experimentalism." American Journal of International Law 111, no. 2: 277-316.

Dudai, Ron. 2017. "Entryism, Mimicry and Victimhood Work: The Adoption of Human Rights Discourse by Right-Wing Groups in Israel." International Journal of Human Rights 21, no. 7: $1-23$.

Edwards, Alice. 2006. "The 'Feminizing' of Torture under International Human Rights Law." Leiden Journal of International Law 19, no. 2: 349-91.

- 2010. Violence against Women under International Human Rights Law. Cambridge, UK: Cambridge University Press.

Engle, Karen. 2005. "Feminism and Its (DIS)contents: Criminalizing Wartime Rape in Bosnia and Herzegovina." American Journal of International Law 99, no. 4: 778-816.

Evatt, Elizabeth. 2002. "Women and Human Rights." Monash University Law Review 28: 1-16.

Finnemore, Martha. 1999. "Are Legal Norms Distinctive?" New York University Journal of International Law and Policy 32: 699-705.

Finnemore, Martha, and Kathryn Sikkink. 1998. "International Norm Dynamics and Political Change." International Organization 52, no. 4: 887-917.

- 2001. "Taking Stock: The Constructivist Research Program in International Relations and Comparative Politics." Annual Review of Political Science 4, no. 1: 391-416.

Flyvbjerg, Bent. 2006. "Five Misunderstandings about Case-Study Research." Qualitative Inquiry 12, no. 2: 219-45.

Foster, Steve, and Bob Ginell. 1999. "Parental Chastisement and Article 3 of the European Convention." Journal of Social Welfare EF Family Law 21, no. 2: 187-93.

Gaer, Felice D. 2007. "Opening Remarks: General Comment No. 2." New York University Law Review 11: $187-200$. 
George, Alexander L., and Andrew Bennett. 2005. Case Studies and Theory Development in the Social Sciences. Cambridge, MA: MIT Press.

Glendon, Mary Ann. 2002. A World Made New: Eleanor Roosevelt and the Universal Declaration of Human Rights. New York: Random House.

Hacker, Daphna. 2015. "Strategic Compliance in the Shadow of Transnational Anti-Trafficking Law." Harvard Human Rights Journal 28: 11-64.

Halley, Janet. 2008. "Rape at Rome: Feminist Interventions in the Criminalization of Sex-Related Violence in Positive International Criminal Law." Michigan Journal of International Law 30, no. 1: 1-123.

2019. "Which Forms of Feminism Have Gained Inclusion?" In Governance Feminism: Notes from the Field, edited by Janet Halley, Prabha Kotiswaran, Rachel Rebouché, and Hila Shamir, 35-39. Minneapolis: University of Minnesota Press.

Halliday, Terence C., and Susan Block-Lieb. 2017. Global Lawmakers: International Organizations in the Crafting of World Markets. Cambridge, UK: Cambridge University Press.

Halliday, Terence C., and Bruce G. Carruthers. 2007. "The Recursivity of Law: Global Normmaking and National Lawmaking in the Globalization of Bankruptcy Regimes." American Journal of Sociology 112, no. 4: 1135-1202.

Ingram, Paul, and Karen Clay. 2000. "The Choice-within-Constraints New Institutionalism and Implications for Sociology." Annual Review of Sociology 26, no. 1: 525-46.

Joachim, Jutta M. 2007. Agenda Setting, the UN, and NGOs: Gender Violence and Reproductive Rights. Washington, DC: Georgetown University Press.

Keck, Margaret E., and Kathryn Sikkink. 1998. Activists beyond Borders: Advocacy Networks in International Politics. Cambridge, UK: Cambridge University Press.

Keller, Helen, and Leena Grover. 2012. "General Comments of the Human Rights Committee and Their Legitimacy." In UN Human Rights Treaty Bodies: Law and Legitimacy, edited by Helen Keller and Geir Ulfstein, 116-98. Cambridge, UK: Cambridge University Press

Koskenniemi, Martti A. 2018. "Conclusion: After Globalisation-Engaging the Backlash." In Globalisation and Governance: International Problems, European Solutions, edited by Robert Schütze, 453-64. Cambridge, UK: Cambridge University Press.

Krahenmann, Sandra. 2012. Positive Obligations in Human Rights Treaties. PhD diss., Graduate Institute of International and Development Studies.

Lagoutte, Stéphanie, Thomas Gammeltoft-Hansen, and John Cerone. 2016. Tracing the Roles of Soft Law in Human Rights. Oxford: Oxford University Press.

Lerner, Natan. 2015. "The UN Convention on the Elimination of All Forms of Racial Discrimination." In The UN Convention on the Elimination of All Forms of Racial Discrimination, edited and revised by Natan Lerner, $i-x x x v i i$. Leiden: Brill Nijhoff.

MacDowell Santos, Cecília. 2018. "Mobilizing Women's Human Rights: What/Whose Knowledge Counts for Transnational Legal Mobilization?" Journal of Human Rights Practice 10, no. 2: 191-211.

MacKinnon, Catharine. 1993. "On Torture: A Feminist Perspective on Human Rights." In Human Rights in the Twenty-First Century: A Global Challenge, edited by Kathleen E. Mahony and Paul Mahoney, 21-32. Leiden: Martinus Nijhoff.

McCrudden, Christopher. 2007. "Judicial Comparativism and Human Rights." In Comparative Law: A Handbook, edited by Esin Örücü and David Nelken, 371-98. Oxford: Hart Publishing.

Merry, Sally Engle. 2006. Human Rights and Gender Violence: Translating International Law into Local Justice. Chicago: University of Chicago Press.

Naftali, Patricia. 2010. "The Subtext of New Human Rights Claims: A Socio-Legal Journey Into the 'Right to Truth."' In Diverse Engagement: Drawing in the Margins, edited by Matthew French, Elina Jokisuu, and Simon Jackson, 118-27. Cambridge, UK: Cambridge University Press.

Normand, Roger, and Sarah Zaidi. 2008. Human Rights at the UN: The Political History of Universal Justice. Bloomington: Indiana University Press.

Posner, Eric. 2014. The Twilight of Human Rights Law. Oxford: Oxford University Press.

Price, Richard. 1998. "Reversing the Gun Sights: Transnational Civil Society Targets Land Mines." International Organization 52, no. 3: 613-44. 
Risse, Thomas, Stephen C Ropp, and Kathryn Sikkink. 1999. The Power of Human Rights: International Norms and Domestic Change. Cambridge, UK: Cambridge University Press.

Rodley, Nigel S. 2002. "The Definition(s) of Torture in International Law." Current Legal Problems 55, no. 1: 467-93.

Seibert, Thomas. 2009. "Turkey Fined for Failing to Protect Women." The National, June 12, https:// www.thenational.ae/world/europe/turkey-fined-for-failing-to-protect-woman-1.523613? videoId $=5771275459001$.

Seibert-Fohr, Anja. 2015. "Judicial Engagement in International Human Rights Comparativism." https://papers.ssrn.com/sol3/papers.cfm?abstract_id $=2641689$.

Shelton, Dinah. 2003. "Law, Non-Law and the Problem of 'Soft Law." In Commitment and Compliance: The Role of Non-binding Norms in the International Legal System, edited by Dinah Shelton, 1-20. Oxford: Oxford University Press.

Simmons, Beth A. 2009. Mobilizing for Human Rights: International Law in Domestic Politics. Cambridge, UK: Cambridge University Press.

Sjöholm, Maria. 2017. Gender-Sensitive Norm Interpretation by Regional Human Rights Law Systems. Leiden: Martinus Nijhoff.

Slaughter, Anne-Marie. 2003. "A Global Community of Courts.” Harvard International Law Journal 44, no. 1: 191-220.

Stoeckl, Kristina. 2016. "The Russian Orthodox Church as Moral Norm Entrepreneur." Religion, State and Society 44, no. 2: 132-51.

UN Secretary General. 1998. Integrating the Gender Perspective into the Work of United Nations Human Rights Treaty Bodies. Doc. HRI/MC/1998/6. Geneva: United Nations

Voeten, Erik. 2010. "Borrowing and Nonborrowing among International Courts." Journal of Legal Studies 39, no. 2: 547-76.

Waldron, Jeremy. 2005. "Torture and Positive Law: Jurisprudence for the White House." Columbia Law Review 105, no. 6: 1681-1750.

Yildiz, Ezgi. 2016. "A Norm in Flux: The Development of the Norm Against Torture under the European Convention from a Macro Perspective." iCourts: The Danish National Research Foundation's Centre of Excellence for International Courts. iCourts Working Paper Series no. 45. - 2020. "A Court with Many Faces: Judicial Characters and Modes of Norm Development in the European Court of Human Rights." European Journal of International Law 31, no. 1: 73-99. 